\title{
Early growth, survival and litter size in Ethiopian Horro sheep
}

\author{
S. Abegaz ${ }^{1 \#}$, D. Gemeda ${ }^{2}$, J.E.O. Rege ${ }^{3}$, J.B. van Wyk ${ }^{1}$, F.W.C. Neser $^{1}$ and G.J. Erasmus $^{1}$ \\ ${ }^{1}$ Dept of Animal Science, University of the Orange Free State, P O Box 339, Bloemfontein 9300, South Africa; ${ }^{2}$ Dept of \\ Animal Science, University of Stellenbosch, P Bag X1, Matieland 7602, South Africa, ${ }^{3}$ International Livestock Research \\ Institute, Addis Ababa, Ethiopia; "Email: Abegaz@landbou.uovs.ac.za
}

\section{Introduction}

A breed characterisation study on Horro hair sheep (for description see Galal, 1983) has been underway at Bako Research Centre in Ethiopia since 1977. In this paper the results of analysis of early growth performance, survival and litter size are presented.

\section{Material and Methods}

The Bako Agricultural Research Centre is located about $250 \mathrm{~km}$ west of Addis Ababa $\left(09^{\circ} 6^{\prime} \mathrm{N}, 37^{\circ} 09^{\prime} \mathrm{E}\right)$ at an altitude of $1650 \mathrm{~m}$. Data were collected from a flock of Horro sheep from 1977 to 1998. The flock was established with 100 ewe lambs. Animals were managed semi-intensively where they grazed during daytime and were housed at night. They were given feed supplements during critical periods. A total of 4031 lamb and 2252 lambing records were used for the analysis of early growth traits (birth and weaning weight), survival and litter size. Important fixed effects to be included in a subsequent genetic analysis on birth and weaning weights were identified using the GLM procedure of SAS (1994). Effects included in the model were sex, type of birth/rearing, year of birth, and parity. Age at weaning was included as a covariate. A similar analysis was done on litter size by including year of lambing and parity effects along with ewe weight at mating as covariate. Survival to weaning was analysed using the CATMOD procedure of SAS (1994) and subclass proportions and estimates of standard errors were computed using the procedure of Rege \& Sherington (1996) as implemented by Rege (1997). Effects included in the analysis were sex, year, type of birth, dam age and birth weight class (categorised arbitrarily to have balanced number of lambs among classes). Genetic analysis for birth and weaning weight was done by sire and animal models using AIREML (Gilmour et al.. 1995).

\section{Results and Discussion}

Least square means of birth and weaning weight and predicted probability of survival are presented in Table 1. Weaning age was $92.5 \pm 0.13$ days. Overall birth and weaning weight were 2.7 and $11.8 \mathrm{~kg}$ respectively. Sex and type of birth had a significant $(\mathrm{P}<0.05)$ effect on birth and weaning weight. Type of birth and lamb birth weight had a significant $(\mathrm{P}<0.01)$ effect on lamb survival.

Table 1 Least square means $( \pm$ S.E.) of birth and weaning weight and predicted probabilities $( \pm$ S.E) of pre-weaning survival.

\begin{tabular}{|c|c|c|c|c|c|c|}
\hline Effect & Level & $\bar{N}$ & $\begin{array}{c}\text { Birth } \\
\text { weight }(\mathrm{kg})\end{array}$ & $\mathrm{n}$ & $\begin{array}{c}\text { Weaning } \\
\text { weight }(\mathrm{kg})\end{array}$ & $\begin{array}{c}\text { Predicted probability } \\
\text { of survival }\end{array}$ \\
\hline Overall & & 3664 & $2.71 \pm 0.02$ & 2752 & $11.81 \pm 0.09$ & $80.5 \pm 1.11$ \\
\hline \multirow[t]{2}{*}{ Sex } & Male & 1872 & $2.77 \pm 0.02$ & 1401 & $12.34 \pm 0.10$ & $79.5 \pm 1.33$ \\
\hline & Female & 1792 & $2.63 \pm 0.02$ & 1351 & $11.27 \pm 0.10$ & $81.4 \pm 1.29$ \\
\hline \multirow[t]{2}{*}{ Litter } & Single & 1917 & $2.93 \pm 0.02$ & - & - & $84.3 \pm 0.01$ \\
\hline & Multiple & 1847 & $2.46 \pm 0.02$ & - & - & $76.0 \pm 1.67$ \\
\hline \multirow[t]{3}{*}{ Type of rearing } & SS & - & - & 1453 & $13.17 \pm 0.08$ & - \\
\hline & TT & - & - & 1164 & $11.96 \pm 0.23$ & - \\
\hline & TS & - & - & 135 & $10.28 \pm 0.09$ & - \\
\hline \multirow{4}{*}{$\begin{array}{l}\text { Birth } \\
\text { class }\end{array}$} & 1 & - & - & - & - & $66.4 \pm 1.95$ \\
\hline & 2 & - & - & - & - & $79.1 \pm 1.49$ \\
\hline & 3 & - & - & - & - & $83.9 \pm 1.44$ \\
\hline & 4 & - & - & - & - & $88.1 \pm 1.82$ \\
\hline
\end{tabular}

$\mathrm{N}=$ Number of records; $\mathrm{SS}=$ Single reared as single; $\mathrm{TT}=\mathrm{Twin}$ reared as twin; $\mathrm{TS}=\mathrm{T}$ win reared as single Birth weight class: $1=\leq 2 \mathrm{~kg} ; 2=>2 \mathrm{~kg}$ but $\leq 2.6 ; 3=>2.6$ but $\leq 3.2 \mathrm{~kg} ; 4=>3.2 \mathrm{~kg}$ 


\section{Short paper and poster abstracts: $38^{\text {th }}$ Congress of the South African Society of Animal Science}

The heritability of birth and weaning weight was $0.25( \pm 0.054)$ and $0.16( \pm 0.049)$ under a sire model and $0.27( \pm 0.034)$ and $0.26( \pm 0.039)$ under an animal model, respectively. Genetic and phenotypic correlations between the two traits were $0.25( \pm 0.021)$ and $0.45( \pm 0.093)$, respectively. Least square means of litter size are shown in Table 2. Overall litter size was 1.34 and it increased with parity of ewes. Ewe weight at mating had a significant (P $<0.05)$ effect on litter size.

Table 2. Least square means ( \pm S.E.) of litter size for year, parity and ewe weight at mating.

\begin{tabular}{llll}
\hline Effect & Level & N & Litter size \\
\hline Overall & & 2213 & $1.34 \pm 0.01$ \\
Parity & 1 & 606 & $1.26 \pm 0.02$ \\
& 2 & 519 & $1.31 \pm 0.02$ \\
& 3 & 424 & $1.38 \pm 0.02$ \\
& 4 & 322 & $1.36 \pm 0.03$ \\
& $\geq 5$ & 342 & $1.44 \pm 0.03$ \\
Ewe weight (Cov.) $^{\text {a }}$ & & & $0.025 \pm 0.01$ \\
\hline${ }^{a}=$ Regression of litter size on ewe weight at mating fitted as a covariate
\end{tabular}

Average pre-weaning daily gain was about $100 \mathrm{~g}$ per day, and this gives about 15 to 16 units of kleiber ratio. This value is lower than values reported for other sheep breeds (Greeff et al., 1993; Van Wyk et al., 1993), but the daily gain of about $100 \mathrm{~g}$ is better than that reported for African fat tailed sheep (Wilson \& Murayi, 1988) or for Djallonké sheep ( Yapi-Gnaore et al., 1997). In this study twins reared as twins were heavier than twins reared as singles. Consistent heritability estimates under both sire and animal models indicate that selection can be applied for birth weight to improve lamb survival and weaning weight. The pre-weaning survival is comparable to the figure of $80 \%$ reported for Yankassa sheep by Osinowo (1993).

\section{Conclusion}

Survival in lambs improved with birth weight, and the effect of type of birth on survival could be partly due to low birth weight. The overall litter size in this study shows that there is reasonable twinning in the breed.

\section{Acknowledgement}

The analysis of the data was partially sponsored by International Livestock Research Institute (ILRI).

\section{References}

Galal, E.S.E., 1983. Sheep Germplasm of Ethiopia. Animal Genetic Resources Information 1/83. FAO, Rome. pp 412.

Gilmour, A.R., Thompson, R., Culis B.R., 1995. Average information REML, an efficient algorithm for variance parameter estimation in linear mixed models. Biometrics 51, 1440.

Greeff, J.C., Scholtz, M.M. and C.Z.Roux., 1993. Preliminary genetic parameters of growth during different growth phases in sheep. S. Afr. J. Anim. Sci. 23, 57.

Osinowo, O.A., Abubakar, B.Y., Olayemi, M.E., Balogun, R.O., Onifade, O.S., Adewuyi, A.A., Trimnell, A.R. and Dennar, F.O., 1993. Preweaning performance of Yankasa sheep under Semi-intensive management. In: Proc. $2^{\text {nd }}$ Biennial Conf. Afri. Small Rumin. Res. Network. ILCA, Addis Ababa, p.65.

Rege, J.E.O., 1997. LOGMLVAR. V 2.0: A computer program for estimating variances of predicted probabilities from maximum likelihood estimates in a logit response function. International Livestock research Institute (ILRI), Addis Ababa, Ethiopia.

Rege, J.E.O. and Shrington J., 1996. A method for estimating sampling variances of predicted probabilities from maximum likelihood estimates in a logit response function. Discovery and Innovation 8,171.

SAS., 1994. SAS User's Guide. SAS Institute Inc., Cary, NC, USA.

Van Wyk, J.B., Erasmus, G.J. and Konstantinov, K.V., 1993 Variance component and heritability estimates of early growth traits in the Elsenburg Dormer sheep stud. S. Afr. J. Anim. Sci. 23, 72.

Wilson, R.T. and Murayi, T.H., 1988. Production characteristics of African Long-Fat-Tailed sheep in Rwanda. Small 
(c) South African Society of Animal Science

Short paper and poster abstracts: $38^{\text {th }}$ Congress of the South African Society of Animal Science Rum. Res. 1,3

Yapi-Gnaore, C.V., Oya, A., Rege, J.E.O. and Dangogo, B., 1997. Analysis of an open nucleus breeding programme for Djallonké sheep in Ivory Coast. 1. Examination of non-genetic factors. Anim. Sci. 64, 291. 